\title{
PHYSIOLOGICAL CORRELATES OF BURROWING IN RODENTS
}

\author{
Richard C. Chapman* and Albert F. Bennett $\dagger$ \\ Department of Zoology, University of California, Berkeley, California 94720, U.S.A.
}

(Received 11 April 1974)

\begin{abstract}
Blood properties of valley pocket gophers, Thomomys bottae, and laboratory rats, Rattus norvegicus, were examined to determine blood buffering capabilities.

2. Hematocrit, plasma proteins and inorganic phosphate levels were not significantly different between these species.

3. Oxygen capacity of the pocket gophers, $23.1 \mathrm{vol} \%$, was greater than that of the rats, $20 \cdot 8 \mathrm{vol} \%$.

4. Bicarbonate concentration of pocket gopher blood, $28 \cdot 1 \mathrm{mM} / \mathrm{l}$, was significantly greater than that of the rats, $19.8 \mathrm{mM} / \mathrm{l}$.

5. The non-carbonic buffering strength as determined from $\mathrm{CO}_{2}$ titration curves of whole blood of pocket gophers, $-2.67 \log p \mathrm{CO}_{2} / \mathrm{pH}$ unit, was greater than that of the rats, $-1.39 \log p \mathrm{CO}_{2} / \mathrm{pH}$ unit.

6. The greater buffering capacity of pocket gopher blood may account for the reduced sensitivity of ventilation rate in response to elevated burrow $\mathrm{CO}_{2}$ concentrations.
\end{abstract}

\section{INTRODUCTION}

THE GAS composition of rodent burrows is often very different from that of environmental air, creating situations of potential respiratory difficulty for these fossorial mammals. Field observations of pocket gopher burrows have revealed $\mathrm{CO}_{2}$ concentrations ranging from 0.6 to 3.8 per cent and $\mathrm{O}_{2}$ concentrations from 6.0 to 21.0 per cent (Kennerly, 1964; McNab, 1966; Darden, 1972). Maximum $\mathrm{CO}_{2}$ concentrations of 6 per cent have been found in burrows of thirteen-lined squirrels (Spermophilus tridecemlineatus) (Studier \& Proctor, 1971). Normal concentrations of $\mathrm{CO}_{2}$ and $\mathrm{O}_{2}$ in air are 0.04 and 20.95 per cent, respectively. The poor circulation of air within burrows accompanied by the respiration of the rodents and soil micro-organisms accounts for the accumulation of high concentrations of $\mathrm{CO}_{2}$ and depletion of $\mathrm{O}_{2}$ within the burrows.

Ventilation in non-burrowing mammals is sensitive to the concentration of $\mathrm{CO}_{2}$ in the inspired air. When the concentration of $\mathrm{CO}_{2}$ in the inspired air is increased, a lowering of body fluid $\mathrm{pH}$ results. The lowered $\mathrm{pH}$ stimulates the respiratory control centers of the central nervous system resulting in an increase in ventilation, such that the partial pressure of $\mathrm{CO}_{2}\left(p \mathrm{CO}_{2}\right)$ in alveolar air remains almost unchanged (Siggaard-Andersen, 1965). The increment in ventilation rate in response to elevated $\mathrm{CO}_{2}$

* Present address: Alaska Co-operative Wildlife Research Unit, University of Alaska, College, Alaska 99701, U.S.A.

† Present address: School of Biological Sciences, University of California, Irvine, California 92664, U.S.A. concentrations in two fossorial rodents, the valley pocket gopher, Thomomys bottae (Darden, 1972), and Merriam's kangaroo rat, Dipodomys merriami (Soholt et al., 1973), has been shown to be significantly less than the response of non-fossorial mammals to the same level of $\mathrm{CO}_{2}$ concentration. Other effects of high $\mathrm{CO}_{2}$ concentrations are heart rate depression and a drop in body temperature. These responses develop only at very high levels of $\mathrm{CO}_{2}$; however, the magnitude of these responses in burrowing mammals also appears to be less than in laboratory mammals (Soholt et al., 1973).

Darden (1972) suggests that the greater insensitivity of fossorial mammals to $\mathrm{CO}_{2}$ may be due to a greater buffering capacity in the body fluids than that found in non-fossorial mammals. Another potential mechanism of increased tolerance is a reduced sensitivity of the respiratory control receptors of fossorial mammals to changes in body fluid pH. Soholt et al. (1973) also believe that the former suggestion seems more likely, since enzymatic function is dependent upon stable $\mathrm{pH}$. However, $\mathrm{pH}$ change might also facilitate enzymatic adaptation to burrowing conditions. In any case, neither theory has been experimentally verified.

The purpose of the present investigation was to examine the blood buffering capabilities of a fossorial rodent, $T$. bottae, compared to the capabilities of a non-fossorial rodent, Rattus norvegicus. Measurements were made of the following blood properties: bicarbonate concentration, inorganic phosphate concentration, oxygen capacity, hematocrit, plasma total protein and non-albumin and albumin fractions, and titration curves for non-carbonic buffers. 
If buffering capacities are indeed greater in fossorial rodents, an examination of these parameters should reveal differences between these species, particularly in carbonic or non-carbonic buffering ability.

\section{MATERIALS AND METHODS}

\section{Experimental animals}

A total of thirteen adult valley pocket gophers, Thomomys bottae (mean weight, $139 \mathrm{~g}$ ), were used during this investigation. All thirteen were trapped in Marin and Contra Costa Counties in California. The pocket gophers were maintained on Berkeley Diet Mouse Breeder Food supplemented every other day with waste vegetable material (potato and carrot peelings, lettuce, celery, etc.). Water was provided ad lib.; however, most of the water needed by the pocket gophers was obtained from the vegetable matter. Temperature was maintained at approximately $20^{\circ} \mathrm{C}$ with a natural photoperiod. The experiments were conducted from October 1973 to March 1974.

Approximately fifteen adult laboratory rats, Rattus norvegicus (mean weight, $396 \mathrm{~g}$ ), were also used. They were given Berkeley Diet Mouse Breeder Food and water ad lib. Temperature was maintained at approximately $20^{\circ} \mathrm{C}$. The photoperiod was $12 \mathrm{~L}-12 \mathrm{D}$.

\section{Blood samples}

Prior to obtaining blood samples, all experimental animals were anesthetized with Nembutal (sodium pentobarbital) in concentrations of $50 \mathrm{mg} / \mathrm{kg}$ body weight. All blood samples were obtained by ventricular heart puncture with either No. 24,26 or 27 sized needles. No. 24 sized needles proved the most satisfactory. Coagulation was prevented by the addition of crystalline sodium heparin to the blood samples.

\section{Hematocrit and oxygen capacity}

Blood samples of approximately $0.25 \mathrm{ml}$ were obtained from nine pocket gophers and nine rats. The samples were placed in heparinized capillary tubes, sealed and centrifuged for $10 \mathrm{~min}$ at $3000 \mathrm{rev} / \mathrm{min}$. The percentage of red blood cell volume in the total volume of the sample was recorded as the hematocrit. The plasma portions of these samples were used in the protein analyses.

Approximately $0.25 \mathrm{ml}$ of blood was obtained from three pocket gophers and six rats. The oxygen capacity of the blood was measured by fully oxygenating the sample and measuring the total amount of oxygen bound at $38^{\circ} \mathrm{C}$. The blood sample was injected into a $25 \mathrm{ml}$ volumetric flask. A gas mixture of $95 \%$ air and $5 \%$ carbon dioxide saturated with water vapor at $38^{\circ} \mathrm{C}\left(\mathrm{pO}_{2}=145\right.$ torr, $p \mathrm{CO}_{2}=35$ torr, $p \mathrm{H}_{2} \mathrm{O}=50$ torr) was slowly metered into the flask for about 4 min. The flask was then sealed and attached to the shaft of a small motor, tilted and rotated at about $20 \mathrm{rev} / \mathrm{min}$, so that the blood sample formed a thin layer on the periphery of the bottom of the flask. The flask was placed in a $38^{\circ} \mathrm{C}$ water-bath and equilibrated for $10 \mathrm{~min}$. At the end of the equilibration period, the sample was removed and analyzed for oxygen content according to the method of Roughton \& Scholander (1943). The oxygen content was expressed as vol \%, corrected to STPD conditions.

\section{Plasma proteins}

Red and white blood cell fractions were cut from the plasma fractions of the capillary tubes used in the hematocrit determinations. Plasma samples of $0.10 \mathrm{ml}$ from four pocket gophers and four rats were used in this experiment. Total protein was determined with the biuret procedure. The non-albumin proteins were precipitated with ether and the albumin-containing solvent was again analyzed with the biuret procedure. Protein content was expressed as $\mathrm{g} / 100 \mathrm{ml}$ plasma.

\section{Phosphate buffers}

The phosphate buffers were assayed by determination of the total amount of inorganic phosphate by the spectrophotometric method outlined by Hawk et al. (1947). The increment in the optical density of samples and standard solutions $(2-8 \mathrm{mg} \%$ ) was read on a Beckman DB spectrophotometer at $660 \mathrm{~nm}$. Blood samples of $0.10 \mathrm{ml}$ were obtained from seven rats and six pocket gophers.

\section{Bicarbonate concentrations}

The bicarbonate-carbonic acid buffer systems were assayed by the determination of bicarbonate concentration under standard conditions. This was done according to the method outlined by Umbreit et al. (1964). The method consisted of equilibrating a $0 \cdot 10-\mathrm{ml}$ blood sample with a gas mixture of $95 \%$ air and $5 \%$ carbon dioxide saturated with water vapor at $38^{\circ} \mathrm{C}\left(\mathrm{pO}_{2}=145\right.$ torr, $p \mathrm{CO}_{2}=35$ torr, $p \mathrm{H}_{2} \mathrm{O}=50$ torr), acidulating the sample and measuring the liberated carbon dioxide manometrically. Bicarbonate concentrations were expressed in $\mathrm{mM} / \mathrm{l}$. Blood samples were obtained from seven pocket gophers and eight rats.

\section{Titration curve for all non-carbonic buffers}

A titration curve for all non-carbonic buffers in whole blood was constructed by varying the $p \mathrm{CO}_{2}$ of the atmosphere in which an in vitro blood sample was exposed and measuring the resulting $\mathrm{pH}$. Two separate curves were constructed for both the pocket gophers and the rats. Approximately $0.6 \mathrm{ml}$ of blood was obtained from each of six rats for the first curve; approximately $1.0 \mathrm{ml}$ from each of four rats for the second curve. For both pocket gopher curves approximately $1.0 \mathrm{ml}$ of blood was obtained from each of four pocket gophers. For each curve the blood samples were pooled, mixed thoroughly and stored on ice between determinations. The equilibration system previously described was utilized. The temperature of the system was regulated at $38^{\circ} \mathrm{C}$. Gas mixtures of varying proportions of $\mathrm{CO}_{2}, \mathrm{O}_{2}$ and $\mathrm{N}_{2}$, saturated with water vapor, were prepared in a 9 1. capacity spirometer $\left(p \mathrm{CO}_{2}=18-216\right.$ torr, $p \mathrm{O}_{2}=142$ torr, $p \mathrm{~N}_{2}=352-550$ torr, $p \mathrm{H}_{2} \mathrm{O}=50$ torr). A $0.4-\mathrm{ml}$ sample of blood was placed in a $25 \mathrm{ml}$ volumetric flask and equilibrated with the gas mixture as described previously for oxygen capacity measurements. The $\mathrm{pH}$, to an accuracy of $\pm 0.02 \mathrm{pH}$ unit, was measured immediately at the end of the equilibration period with a Beckman Micro Blood pH Assembly and expanded scale pH meter. 


\section{Statistics}

All linear regressions are the best computed leastsquares fit to the data. Mean values are reported with standard errors; 95 per cent confidence limits are used to estimate significance. The difference between mean values was tested with a Student's $t$-test.

\section{RESULTS}

\section{Hematocrit and oxygen capacity}

The average hematocrit for the pocket gophers, $46 \cdot 1 \%( \pm 1 \cdot 3)$, is not significantly greater $(P>0 \cdot 1)$ than that for the rats, $43 \cdot 7 \%( \pm 1 \cdot 3)$.

The average oxygen capacity of pocket gopher blood, $23.1 \mathrm{vol} \%( \pm 0.33)$, is slightly greater $(0.05>P>0.02)$ than that of rat blood, $20.8 \mathrm{vol} . \%$ $( \pm 0 \cdot 55)$.

\section{Plasma proteins}

The average total protein content of blood plasma for the pocket gophers, $6.3 \mathrm{~g} / 100 \mathrm{ml}( \pm 0.13)$, is identical to that for the rats, $6 \cdot 3 \mathrm{~g} / 100 \mathrm{ml}( \pm 0 \cdot 20)$. Values of non-albumin protein are slightly higher in the pocket gophers, $0.99 \mathrm{~g} / 100 \mathrm{ml}( \pm 0.072)$, than in the rats, $0.70 \mathrm{~g} / 100 \mathrm{ml}( \pm 0.074)(0.05>P>0.02)$.

\section{Phosphate buffers}

The average concentration of inorganic phosphate in the blood of the rats, $4.9 \mathrm{mg} \%( \pm 0.37)$, is not significantly different $(P>0.1)$ from that of the pocket gophers, $4 \cdot 2 \mathrm{mg} \%( \pm 0 \cdot 15)$.

\section{Bicarbonate concentration}

The average bicarbonate concentration in the blood for the pocket gophers, $28.1 \mathrm{mM} / 1 .( \pm 0.89)$, is significantly greater $(P<0.001)$ than that for the rats, $19 \cdot 8 \mathrm{mM} / 1 .( \pm 1 \cdot 0)$.

\section{Titration curves for all non-carbonic buffers}

Figures 1 and 2 show the regression lines of the titration curves for all non-carbonic buffers for the pocket gophers and rats, respectively. SiggaardAndersen (1965) has found linear approximation represents a satisfactory description of this relationship of $\mathrm{pH}$ as a function of $\log p \mathrm{CO}_{2}$. The average non-carbonic buffering strength of pocket gopher blood is $-2.67 \log p \mathrm{CO}_{2} / \mathrm{pH}$ unit, and of rat blood, $-1.39 \log p \mathrm{CO}_{2} / \mathrm{pH}$ unit. The non-carbonic buffering systems of the pocket gophers are, therefore, more effective in retarding $\mathbf{p H}$ change than those of the rats.

\section{DISCUSSION}

\section{Hematocrit and oxygen capacity}

The hematocrits measured are very similar to those reported for laboratory rats $(46 \%)$ and other non-ungulate mammals $(40-53 \%$ ) (Altman \& Dittmer, 1971). The oxygen capacity values of the rats in this study are higher than those previously

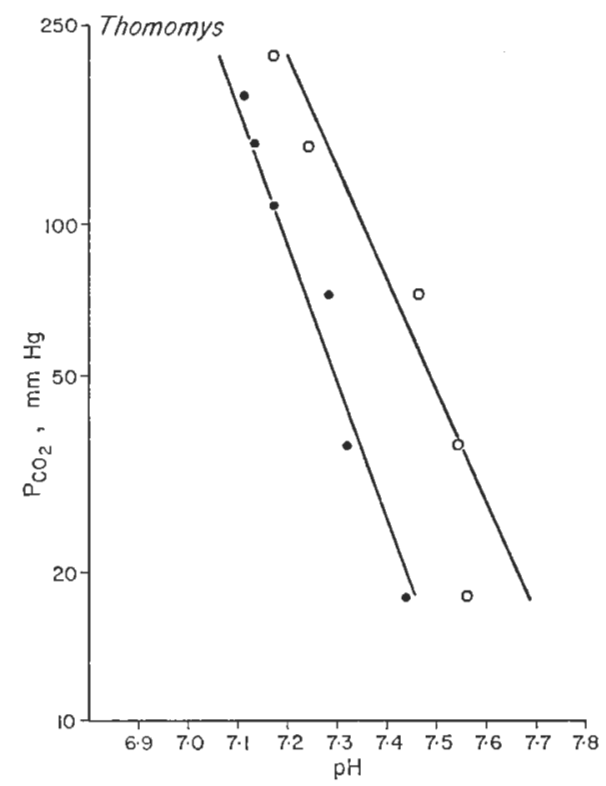

Fig. 1. The pH of whole blood of the pocket gophers (T. bottae) at $38^{\circ} \mathrm{C}$ as a function of $p \mathrm{CO}_{2}$. $\bullet$, Experimental points for regression line $1(\mathrm{pH}=7.90-0.363 \mathrm{log}$ $\left.p \mathrm{CO}_{2}\right) ; O$, regression line $2(\mathrm{pH}=8 \cdot 10-0.387 \mathrm{log}$ $p \mathrm{CO}_{2}$ ).

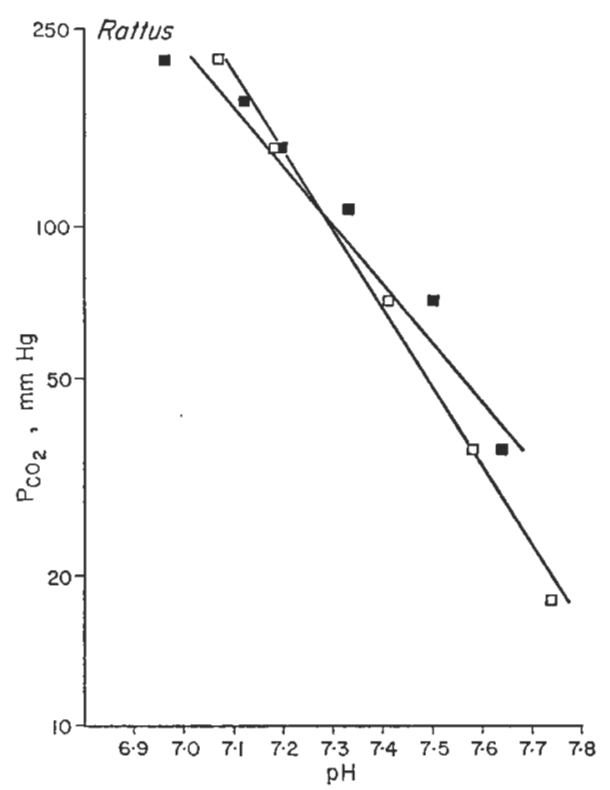

Fig. 2. The $\mathrm{pH}$ of whole blood of the laboratory rats $(R$. norvegicus) at $38^{\circ} \mathrm{C}$ as a function of $p \mathrm{CO}_{2} . \square$, Experimental points for regression line $1(\mathrm{pH}=9.02-0.862 \mathrm{log}$ $\left.p \mathrm{CO}_{2}\right) ; \square$, regression line $2(\mathrm{pH}=8.53-0.622 \mathrm{log}$ $p \mathrm{CO}_{2}$ ). 
reported, 18.1 vol \% (Burke, 1953). The oxygen capacity values of pocket gopher blood are higher than those reported for most non-diving mammals $(11 \cdot 5-24.0 \mathrm{vol} \%)$. However, there is no taxonomic relationship of oxygen capacity in mammals, and it appears to be species-specific (Burke, 1953).

In unoxygenated blood, i.e. blood that has passed through the capillaries, the hemoglobin plays an important role in preventing $\mathrm{pH}$ change and in transporting $\mathrm{CO}_{2}$ from the tissues to the lungs. Since oxygen capacity is higher in the pocket gophers, hemoglobin levels may also be higher, improving the buffering capacity of the blood.

\section{Blood buffering}

The bicarbonate-carbonic acid system, as assayed by the bicarbonate content of the blood, appears much better developed in the pocket gophers than in the rats. Many of the values reported for other mammals are not significantly different from that of the pocket gophers-man, $27.0 \mathrm{mM} / 1$; cat, 20.4 $\mathrm{mM} / 1$. ; cattle, $31.0 \mathrm{mM} / 1$.; $\operatorname{dog}, 21.4 \mathrm{mM} / 1$.; dolphín, $30.9 \mathrm{mM} / 1$.; guinea pig, $22.0 \mathrm{mM} / 1$; hamster, 37.3 $\mathrm{mM} / 1$; hibernating hamster, $42.4 \mathrm{mM} / 1$; horse, $28.1 \mathrm{mM} / 1$.; rabbit, $22 \cdot 8,18 \cdot 0 \mathrm{mM} / 1$; rat, $20 \cdot 8$, $24.0 \mathrm{mM} / 1$.; sheep, $26.2 \mathrm{mM} / 1$; ground squirrel, $20.5 \mathrm{mM} / 1$; ; hibernating ground squirrel, $38.6 \mathrm{mM} / 1$. (Altman \& Dittmer, 1971). The pocket gopher bicarbonate concentration is, however, higher than all other rodents examined except the hamster and hibernating ground squirrel. The greater levels of bicarbonate in the latter animals may be directly related to hibernation.

The greater buffering ability of pocket gopher blood is also manifested in the titration curve for non-carbonic buffers. The buffering value for the pocket gophers, $-2.67 \log p \mathrm{CO}_{2} / \mathrm{pH}$ unit, is greater than that for the rats, $-1.39 \log p \mathrm{CO}_{2} / \mathrm{pH}$ unit, and also that reported for man, $-1.57 \log p \mathrm{CO}_{2} / \mathrm{pH}$ unit (Siggaard-Andersen, 1965). The intercept (vertical position) of the titration curve is influenced by diet or the addition of non-volatile acids (e.g. lactic acid), but the slope of the curve is thought to reflect the concentration and composition of the non-carbonic blood buffers: hemoglobin, plasma proteins, phosphates and non-protein thiol groups. Since inorganic phosphate levels are low in both pocket gopher and rat blood, it might be concluded that the protein buffers are responsible for its greater $\mathrm{pH}$ stability. Quantitatively, there was no difference in the plasma proteins of the two animals investigated; however, qualitative differences (i.e. differences in amino acid composition) have not been studied. Hemoglobin concentrations are perhaps higher in pocket gopher blood than in most other mammals (see above).

Although the blood buffering capabilities appear to be better in pocket gophers, no whole-body buffer curves, measuring the response of blood $\mathrm{pH}$ to in vivo carbon dioxide exposure, have been constructed for any fossorial mammal. The determination of such a response is clearly indicated.

\section{Physiological correlates of burrowing}

The problem facing fossorial mammals encountering high $\mathrm{CO}_{2}$ concentrations is one of chronic respiratory acidosis. The extent of change in $\mathrm{pH}$ of the body fluids in a mammal challenged by high levels of $\mathrm{CO}_{2}$ in the inspired air is determined by the effectiveness of three compensatory mechanisms: (1) the magnitude of the ventilatory response evoked, (2) the capacity of the blood and tissue buffer systems and (3) the efficiency of the renal adjustment (Darden, 1972).

The magnitude of the ventilatory response evoked by high levels of $\mathrm{CO}_{2}$ is reduced in fossorial mammals (Darden, 1972; Soholt et al., 1973). The reduced breathing may prevent excessive respiratory water loss (however, the humidity in most burrow systems is high) or excessive dust inhalation while digging (Scholander et al., 1943; Irving et al., 1956). Also, it appears that fossorial mammals may experience a wider range of $\mathrm{CO}_{2}$ concentration at a reduced mechanical energy cost of breathing (Milic-Emili \& Petit, 1960; Darden, 1972). However, reduced ventilation does not facilitate loss of $\mathrm{CO}_{2}$ through the lungs. Therefore, adaptations in the renal and buffer systems of the body may be necessary.

Darden (1972) indicated that the rate of renal adjustment during chronic hypercapnia, as indicated by excretion of $\mathrm{NH}_{4}^{+}, \mathrm{Cl}^{-}, \mathrm{Na}^{+}$and $\mathrm{K}^{+}$, is rapid. The present investigation has shown relatively high bicarbonate concentrations and a greater strength of the non-carbonic blood buffers in pocket gophers. This tends to confirm the hypothesis that blood buffering is greater in pocket gophers than in nonfossorial mammals. Indeed, it appears that the blood buffers and the renal system are compensating for the depressed response of the respiratory system to elevated $\mathrm{CO}_{2}$ concentrations.

Acknowledgements-This paper is part of a Senior Honors thesis submitted to the Department of Zoology, University of California, Berkeley, by R. C. C. We wish to thank Dr. Paul Licht for the use of equipment and Dr. James L. Patton for the use of pocket gopher traps and the Museum of Vertebrate Zoology animal room.

\section{REFERENCES}

Altman P. L. \& Ditrmer D. S. (1971) Respiration and Circulation. Federation of American Societies for Experimental Biology, Bethesda.

BURKe J. D. (1953) Oxygen capacity in mammals. Physiol. Zoöl. 26, 259-266.

DARDEN T. R, (1972) Respiratory adaptations of a fossorial mammal, the pocket gopher (Thomomys bottae). J. comp. Physiol. 78, 121-137. 
HaWk P. B., Osec B. L. \& Summerson W. H. (1947) Practical Physiological Chemistry, 12th Edn., Blakiston, Philadelphia.

Irving L., Peyton L. J. \& Monson M. (1956) Metabolism and insulation of swine as bare-skinned mammals. J. appl. Physiol. 9, 421-442.

KENNERLY T. E., JR. (1964) Microenvironmental conditions of the pocket gopher burrow. Texas J. Sci. 16, $395-441$.

MCNAB B. K. (1966) The metabolism of fossorial rodents: a study of convergence. Ecology 47, 712-733.

Milic-Emili G. \& Petrt J. M. (1960) Mechanical effiiciency of breathing. J. appl. Physiol. 15, 359-362.

Roughton F. J. W. \& Scholander P. F. (1943) Micro gasometric estimation of the blood gases-I. Oxygen. J. biol. Chem. 148, 541-550.

Scholander P. F., Irving L. \& Grinnell S. W. (1943) Respiration of the armadillo with implications to its burrowing ability. J. cell. comp. Physiol. 21, 53-63.
SiggaArd-Andersen D. (1965) The Acid-base Status of the Blood, 3rd Edn. Williams \& Wilkins, Baltimore. Soholt L. F., Yousef M. K. \& Dill D. B. (1973) Responses of Merriam's kangaroo rats, Dipodomys merriami, to various levels of carbon dioxide concentration. Comp. Biochem. Physiol. 45A, 455-462.

STUdier E. H. \& Proctor J. W. (1971) Respiratory gases in burrows of Spermophilus tridecemlineatus. $J$. Mammal. 52, 631-633.

UMBreIt W. W., Burris R. H. \& StaufFer J. F. (1964) Manometric Techniques: A Manual Describing Methods Applicable to the Study of Tissue Metabolism, 4th Edn. Burgess, Minneapolis.

Key Word Index-Bicarbonate; blood; buffering; burrowing; carbon dioxide; fossorial; hematocrit; oxygen capacity; $\mathrm{pH}$; phosphate; plasma protein; Rattus; rodent; Thomomys. 